J. Clin. Chem. Clin. Biochem.

Vol. 20, 1982, pp. 825-831

\title{
Solid Phase Antigen Luminescent Immunoassays (SPALT) for the Determination of Insulin, Insulin Antibodies and Gentamicin Levels in Human Serum
}

By W. G. Wood, H. Fricke

Klinik für Innere Medizin (Direktor: Prof. Dr. P. C. Scriba)

L. von Klitzing

Klinisch-Experimentelle Forschungseinrichtung im Transitorium, Medizinische Hochschule Lübeck

\author{
C. J. Strasburger and P. C. Scriba
}

Klinik für Innere Medizin (Direktor: Prof. Dr. P. C. Scriba)

Medizinische Hochschule Lübeck

(Received Aprị 20/July 27, 1982)

Summary: We describe an interesting and novel alternative to conventional immunoassay techniques for the measurement of antigens and antibodies in body fluids.

The label used for all assays is a pyruvate kinase-IgG conjugate of the relevant second (species-specific) antibody. All assays follow the same principle in which a solid phase antigen is used to adsorb unreacted first (substance-specific) antibody following a conventional antibody-antigen reaction in a liquid phase. After washing, the solid phase antigenfirst antibody is allowed to react with the labelled second antibody. The solid phase is then washed and the pyruvate kinase bound to the solid phase is used to generate ATP which is measured kinetically in a luminometer.

Assays are described for insulin, insulin antibodies and gentamicin to demonstrate both the versatility and sensitivity of this type of assay.

The insulin assay häd a lower detection limit of under $0.25 \mu \mathrm{U}$ per tube and was comparable with the radioimmunoassay used for routine purposes both in sensitivity and reproducibility. The insulin antibody assay correlated well with the radiometric determination used routinely in the laboratory.

The gentamicin assay correlated well with the routine commercial radioimmunoassay and also had comparable coefficients of variation.

In all casses, the inter- and intrâ-assay variation was under $10 \%$ in the range of interest.

Solid Phase Anțigen Luminèsżenżimmunoassays (SPALT) für die Bestimmung von Insulin, Insulin-Antikörper und Gentamicin im menschlichen Serum

Zusammenfassung: Es wird eine Alternative zu der herkömmlichen Immunoassay-Technik für die Bestimmung von Antigenen und Antikörpern in biologischen Flüssigkeiten beschrieben.

Allen Assays liegt das gleiche Prinzip zugrunde, wonach zunächst eine Antigen-Antikörper-Reaktion abläuft. Durch nachfolgende Zugabe des gleichen, jedoch an einen festen Träger gebundenen Antigens werden die noch freien Antikörper àbgefangen. Dịese „,ersten“ Antikörper stellen das Antigen eines „,zweiten“ Antikörpers (Pyruvatkinase-IgGKonjugat) dar: hiermit ist es möglich, eine dem „ersten“ Antikörper entsprechende Menge Pyruvatkinase an das Trägermaterial zu binden. 
In dem anschließenden Bestimmungsansatz bildet dieses Enzym ATP, dessen Synthese-Kinetik in einem Luminometer gemessen wird. An den Beispielen der Insulin-, Insulin-Antikörper- und Gentamicinbestimmungen wird die Empfindlichkeit und die Vielseitigkeit dieser Methode demonstriert.

Bei der Insulinbestimmung liegt die Nachweisgrenze unter $0,25 \mu \mathrm{U}$ im Ansatz und ist somit vergleichbar mit dem herkömmlichen Radioimmunoassay, sowohl was Empfindlichkeit als auçh die Reproduzierbarkeit bețifft. Das entsprechende gilt auch fưr die Insulin-Antikörper- und Gentamicinbestimmung.

Die Variationskoeffizienten, sowohl innerhalb einer Meßreihe als auch von Tag zu Tag, liegen deutlich unter 10\%.

\section{Introduction}

The use of a solid-phase covalently-coupled antigen opens up a new vista for immunoassays which use a single "tracer", namely a labelled second antibody $(1,2)$. The label used in this series of experiments was a pyruvate kinase-IgG conjugate prepared in an analogous way to a transferrin conjugate, the method having recently been published (3).

The choice of a proteohormone, therapy-induced antibodies and a hapten have been chosen to demonstrate both the versatility and sensitivity of the system.

Activated cellulose was used as the support for the antigen after experiments with alternatives had led to unsatisfactory results.

Not only the choice of assay buffer but also the choice of wash solution influenced both the sensitivity and unspecific binding of the assays.

The assays here described can be seen as a further development of luminescent immunoassays which can be used routinely.

The use of such a system brings potential problems, . especially in the determination of haptens, where the conjugate used as immunogen must be known. The conjugate-protein (e.g. bovine serum albumin) must not be used either to saturate free binding sites on the matrix, or as a component of the assay buffer.

The positive effect of such an assay system is that potential interfering compounds (e.g. sodium azide as preservative) are removed from the system before the label comes into contact with the first antibodyantigen complex.

The assays are comparable with radioimmunoassays both in sensitivity and in precision, and are not limited by problems of molecular weight or quenching as are certain chemiluminescent assays (4).

\section{Materials and Methods \\ Materials}

Donkey-anti-rabbit-IgG and rabbit-anti-guinea pig-lgG antisera were purchased from Wellcome, Burgwedel, FRG.

Pyruvate kinase was purchased from Boehringer-Mannheim, Mannheim, FRG., or from Sigma, Munich, FRG.
Microcrystalline cellulose, $m$-maleimidobebèzoyl:N-hydroxysuccinimide, adenosine diphosphate (ADP), phosphoenol pyruvate, bovine and porcine insulin were obtained from Sigma, Munich, FRG.

Sodium metaperiodäte, sodium borohy dride, sodium cyanoborohydride and all buffer reagents were purchased from Merck, Darmstadt, FRG. The antibodies to insulin were donated by Wellcome, Burgwedel, FRG. The gentamicin antibodies were raised in rabbits in the hospital animal house.

The luminometer (LKB 1250), ATP-monitoring reagent and accessories were donated by LKB, Düsseldorf, FRG and Wallac Oy, Turku, SF.

Cellulose activation and coupling of antigens

The activation of the cellulose with sodium metaperiodate, with the subsequent coupling and stabilisation of the insulin and gentamicin was carried out as already published for transferrin (3).

Assay of insulin in serum

Table 1 shows the various assay schemes for the insulin determination. Figure 1 shows the insulin assay as an example of the solid phase antigen luminescent technique (SPALT) here described.

Assay of serum gentamicin levels

Table 2 shows the competitive and sequential SPALT assays for the determination of gentamicin' in serum. In the case of the competitive assay, the solid-phase gentamicin must first be titrated to ensure that the correct amount of solid-phase antigen is present in the system.

\section{Determination of insulin=antibodies in human serum}

Table 3 shows the incubation scheme for this assay. As can be seen, one can test the specificity of the auto-antibodies by varying the solid-phase antigen. In this case, the solid phase antigen is either bovine insulin or porcine insulin. For a general antibody detection, a mix ture of the two solid-phase antigens can be used. The determination of insulin antibodies follows the principle of the RAST-tests from Pharmacia (Uppsala, S).

\section{Comparative assays}

The assays used as comparison for the insulin and gentamicin determinations were radioimmunoassays, (Insulin - INSIK 3 CIS (Isotopendienst West, Dreieich, FRG) and Gentamicin RIA - Diagnostic Products Corporation, (Hermann Biermann, Bad Nauheim, FRG.)).

The detection of insulin antibodies was performed by allowing the patient serum react with radioactive insulin, followed by precipitation of the immunoglobulins with polyethylene glycol $(200 \mathrm{~g} / \mathrm{l})$

Preparation of the labelled second antibody

The conjugation of the immunoglobulin fraction of the second antibody with pyruvate kinase was carriedyout using the method 
Tab. 1. The five insulin assay incubation schemes used in this study

\begin{tabular}{|c|c|c|c|c|c|}
\hline Assay & $\mathbf{A}$ & B & $\mathrm{C}$ & $\mathrm{D}$ & E \\
\hline $\begin{array}{l}\text { Serum/standard volume }(\mu l) \\
\text { Guinea pig-anti insulin }(1: 20000)(\mu l) \\
\text { Assay buffer }(\mu l)\end{array}$ & $\begin{array}{l}100 \\
100 \\
-\end{array}$ & $\begin{array}{l}100 \\
100 \\
-\end{array}$ & $\begin{array}{l}100 \\
100 \\
-\end{array}$ & $\begin{array}{r}100 \\
100 \\
50\end{array}$ & $\begin{array}{l}100 \\
100 \\
100\end{array}$ \\
\hline Incubation time $(\mathrm{h}) /$ temperature $\left({ }^{\circ} \mathrm{C}\right)$ & $18 / 4$ & $18 / 4$ & $24 / 4$ & $24 / 4$ & $24 / 4$ \\
\hline Microcrystalline cellulose-insulin (dilution $1: 100$ ) in assay buffer $(\mu 1)$ & 100 & 100 & 100 & 100 & 100 \\
\hline Incubation time $(\mathrm{h}) /$ temperature $\left({ }^{\circ} \mathrm{C}\right)$ & $6 / \mathrm{RT}^{+}$ & $3 / \mathrm{RT}$ & $8 / 4$ & $24 / 4$ & $24 / 4$ \\
\hline
\end{tabular}

In all assays, the microcrystalline cellulose was washed twice with $1 \mathrm{ml}$ wash buffer followed by centrifugation at $3000 \mathrm{~g}$ for $10 \mathrm{minutes}$ at $4^{\circ} \mathrm{C}$.

Pyruvate-kinase labelled anti-guinea pig IgG - (1:100 dilution) $(\mu \mathrm{l})$

$\begin{array}{lllll}100 & 100 & 100 & 100 & 100 \\ 1.5 / \mathrm{RT} & 2 / \mathrm{RT} & 18 / 4 & 24 / 4 & 24 / 4\end{array}$

Incubation time $(\mathrm{h}) /$ temperature $\left({ }^{\circ} \mathrm{C}\right)$

$\begin{array}{llll}1.5 / \mathrm{RT} & 2 / \mathrm{RT} \quad 18 / 4 \quad 24 / 4 \quad 24 / 4\end{array}$

The wash procedure was repeated as described above and the washed cellulose-bound pyruvate kinase labelled second antibody used to generate ATP from ADP and phosphoenal pyruvate in the presence of a firefly luciferase/luciferin preparation. The ATPproduction was measured kinetically in a luminometer as already described for the serum transferrin assay (1).

$+\mathrm{RT}$ - ambient temperature, in these experiments $18-21^{\circ} \mathrm{C}$.

1

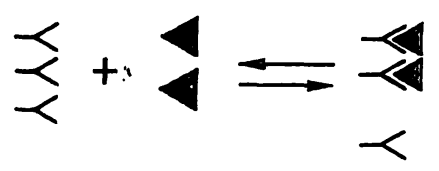

2

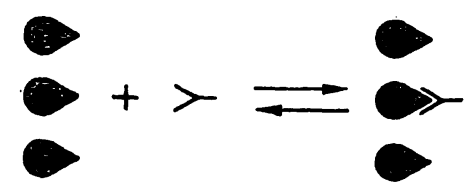

3

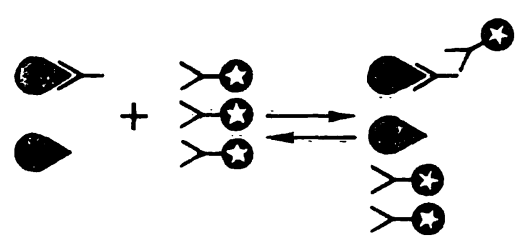

4

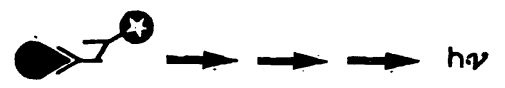

Fig. 1. SPALT principle 1. This shows a conventional antibodyantigen reaction which takes place in a liquid phase.

SPALT principle 2. The unreacted antibody is allowed to react with an excess of solid phase antigen.

SPALT principle 3. After washing and centrifugation, the solid phase is allowed to react with the labelled second antibody.

SPALT principle 4. The solid phase is then washed once more and then used to generate ATP, which is allowed to react with the luciferin-luciferase system to generate light $(h \cdot v)$.

This is the scheme for the sequential asssy. The competitive assay uses less solid phase antigen and combines the first two steps.

\section{Solid phase antigen}

Antigen in the sample

First antibody

Pyruvate kinase labelled second antibody
Tab. 2. Competitive and sequential SPALT assays for serum gentamicin assays.

\begin{tabular}{lcc}
\hline Assay & $\begin{array}{l}\text { Compe- } \\
\text { titive }\end{array}$ & $\begin{array}{l}\text { Sequen- } \\
\text { tial }\end{array}$ \\
\hline $\begin{array}{l}\text { Standard/serum }-(1: 100 \text { dilution with } \\
\text { assay buffer })(\mu l)\end{array}$ & 100 & 100 \\
Rabbit-anti-gentamicin(1:1000 dilution $)(\mu 1)$ & 100 & 100 \\
Cellulose-gentamicin $(1: 100$ dilution $)(\mu \mathrm{l})$ & 20 & 0
\end{tabular}

Incubation time for both assays $30 \mathrm{~min}$ at ambient temperature on a vibrator.

Cellulose-gentamicin (1:100 dilution) $(\mu \mathrm{l}) \quad 0 \quad 100$

Incubation time (min)

$0 \quad 30$

Both assays were subjected to the same washing procedure as in Table 1.

Pyruvate kinase labelled anti-rabbit IgG $\quad 100 \quad 100$ (1:50 dilution) $(\mu \mathrm{l})$

Incubation time ( $\mathrm{min}$ )

$60 \quad 60$

Again, both assays were subjected to the same washing step as in table 1 , followed by the same detection method for the ATP-production.

All incubation steps were carried out at room temperature on a vibrator in order to keep the cellulose suspended.

of Kitagawa \& Aikawa (5), in which the heterobifunctional reagent $m$-maleimidobenzoyl-N-hydroxysuccinimide acted as a linking agent. The immunoglobulin fraction of the respective second antibody was prepared by precipitation with polyethylene glycol $(200 \mathrm{~g} / 1)$, followed by resuspension in $0.15 \mathrm{~mol} / \mathrm{l}$ sodium chloride. This precipitation and resuspension was repeated, the resulting solution of immunoglobulins being coupled in an analogous way to transferrin (3) to the pyruvate kinase.

Separation of the reaction mix ture was performed using an Ultrogel A6 column $(100 \times 2.5 \mathrm{~cm})$, fractions containing both pyruvate kinase and immunological activity being pooled, portioned and lyophilised.

Preparation of the assay buffer and wash solutions The assay buffer used for all assays consisted of the following components:

$0.05 \mathrm{~mol} / \mathrm{l}$ TRIS- $\mathrm{HCl}, 2 \mathrm{~g} / \mathrm{l}$ bovine serum albumin, $0.01 \mathrm{~mol} / 1$ potassium chloride adjusted to $\mathrm{pH} 7.8$. 
The wash solution consisted of equal volumes of assay buffer and $1.5 \mathrm{~mol} / \mathrm{l}$ potassium chloride.

The buffer used in the light-generation step was identical with that used in the transferrin assay already published, (3), as was the concentration of the light-initiation mixture.

Quantification of the immunoreactive solid-phase antigen

Dilutions of well-washed solid-phase antigen were assayed in the normal radioimmunoassay in the same way as serum samples. The removal of antibody from the reaction mixture by the solid-phase antigen resulted in a lower tracer binding in the liquid-phase. This method allows a good estimate of the degree of immunoreactive antigen to be made.

Tab. 3. Insulin antibody SPALT assay scheme, showing two alternative methods of obtaining a "titer" measurement.

\section{Method 1}

$100 \mu \mathrm{l}$ cellulose-insulin (bovine or porcine) 1:100 dilution in assay buffer.

$100 \mu l$ assay buffer.

Incubate $18 \mathrm{~h}$ at $4^{\circ} \mathrm{C}$.

Wash as in the insulin and gentamicin assays.

$100 \mu l$ sheep-anti-human IgG-pyruvate kinase 1:100 dilution in assay buffer.

Incubate $2 \mathrm{~h}$ at room temperature on a vibrator.

Wash as above and measure the ATP-production as in the insulin and gentamicin assays.

The results are expressed as the ratio between the signal from the serum to be measured to that in the negative control.

Values over 1.50 are to be regarded as positive.

\section{Method 2}

The method is principally the same as above, except that the serum to be tested is diluted with negative control serum in dilution steps 1 part serum +9 parts negative control serum, covering the range $1: 10$ to $1: 10000$.

This allows an estimate of the antibody "titer". When the ratio, as described above, falls under 1.50 , the serum or serum dilution is regarded as negative.

The factor 1.50 encompasses a +4 standard deviation range above the negative control value determined from 100 blood donors.

\section{Results and Discussion}

Figure 2 shows a standard curve for insulin and table 4 the results from the different incubation schemes, the latter being expressed in tabular form. Figures 3 and 4 show the gentamicin sequential and competitive assays. Table 5 shows correlation data between the routine radioimmunoassays and the corresponding SPALT assays for both gentamicin and insulin.

Table 6 shows comparisons between the insulin-antibody assays, using sera chosen specially because of the absence of antibodies to both bovine and porcine insulin. Normally, insulin antibodies, when present, react with both porcine and bovine tracer, irrespective of the insulin preparation administered.

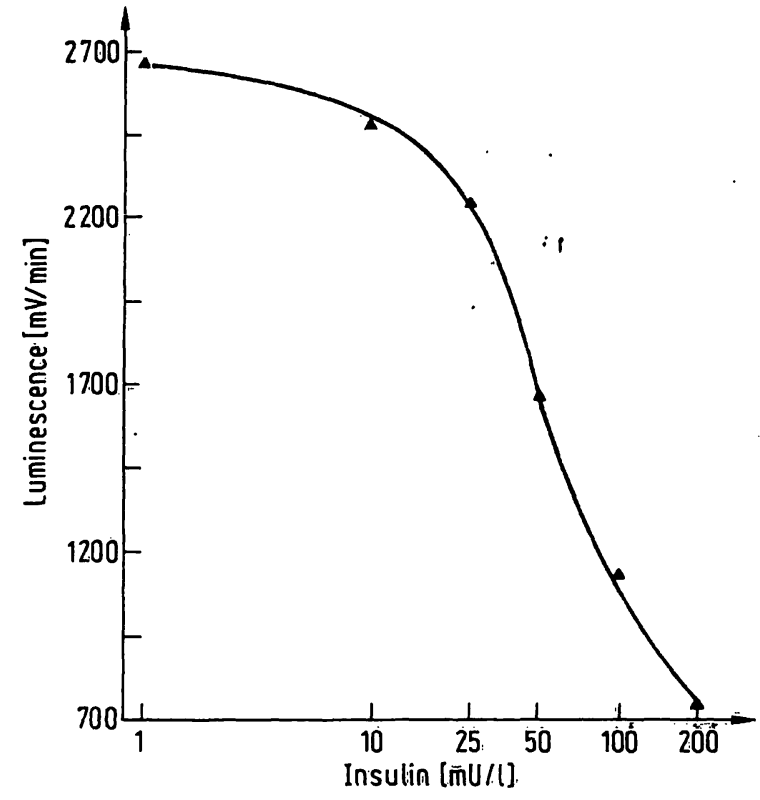

Fig. 2. This shows a standard curve for insulin using assay $\mathrm{E}$ in table 4 as an example. The curve is plotted on semilog co-ordinates.

Tab. 4. Typical standard cựve data for the assays shown in table 1.

\begin{tabular}{|c|c|c|c|c|c|}
\hline Assay & $\mathbf{A}$ & B & $\mathrm{C}$ & $\ddot{D}$ & E \\
\hline $\begin{array}{l}\text { Standard } \\
\text { concentrations } \\
(\mathrm{mU} / \mathrm{l})\end{array}$ & \multicolumn{5}{|c|}{ Signal in $\mathrm{mV} / \mathrm{min}$} \\
\hline 0 & $\begin{array}{l}316 \\
334\end{array}$ & $\begin{array}{l}561 \\
520\end{array}$ & $\begin{array}{l}839 \\
872\end{array}$ & $\begin{array}{l}2112 \\
2070\end{array}$ & $\begin{array}{l}2658 \\
2598\end{array}$ \\
\hline 10 & $\begin{array}{l}239 \\
251\end{array}$ & $\begin{array}{l}471 \\
451\end{array}$ & $\begin{array}{l}708 \\
793\end{array}$ & $\begin{array}{l}2022 \\
2046\end{array}$ & $\begin{array}{l}2526 \\
2418\end{array}$ \\
\hline 25 & $\begin{array}{l}203 \\
198\end{array}$ & $\begin{array}{l}333 \\
323\end{array}$ & $\begin{array}{r}487 \\
468\end{array}$ & $\begin{array}{l}1782 \\
1772\end{array}$ & $\begin{array}{l}2221 \\
2226\end{array}$ \\
\hline 50 & $\begin{array}{l}141 \\
141\end{array}$ & $\begin{array}{l}247 \\
253\end{array}$ & $\begin{array}{l}388 \\
362\end{array}$ & $\begin{array}{l}1320 \\
1314\end{array}$ & $\begin{array}{l}1686 \\
1619\end{array}$ \\
\hline 100 & $\begin{array}{l}125 \\
128\end{array}$ & $\begin{array}{l}143 \\
147\end{array}$ & $\begin{array}{l}159 \\
199\end{array}$ & $\begin{array}{l}798 \\
721\end{array}$ & $\begin{array}{l}1134 \\
1116\end{array}$ \\
\hline 200 & $\begin{array}{l}114 \\
109\end{array}$ & $\begin{array}{l}105 \\
109\end{array}$ & $\begin{array}{l}130 \\
132\end{array}$ & $\begin{array}{l}654 \\
642\end{array}$ & $\begin{array}{l}714 \\
678\end{array}$ \\
\hline $\begin{array}{l}\text { Unspecific binding } \\
\text { (UB) }\end{array}$ & $\begin{array}{l}45 \\
54\end{array}$ & $\begin{array}{l}65 \\
71\end{array}$ & $\begin{array}{l}28 \\
31\end{array}$ & $\begin{array}{l}432 \\
436\end{array}$ & $\begin{array}{l}451 \\
451\end{array}$ \\
\hline $\begin{array}{l}\text { Ratio UB: Zero } \\
\text { standard }\end{array}$ & 0.15 & 0.12 & 0.03 & 0.21 & 0.17 \\
\hline
\end{tabular}

In assays $A$ \& $C$ the cellulose was transferred to a fresh tube before the ATP assay was carried out.

The assay codes are the same as in table 1 .

All values above are corrected for unspecific binding.

Assay E was chosen as the "routine" assay, to cover the range $10-200 \mathrm{mU} / 1$.

Täble 7 shows precision data from both RIEA and SPALT assaȳs.

As a result of the data in tables 5 and 7 , specific recovery experiments were considered to be superfluous, as the results from both methods are seen tộ be the same. 


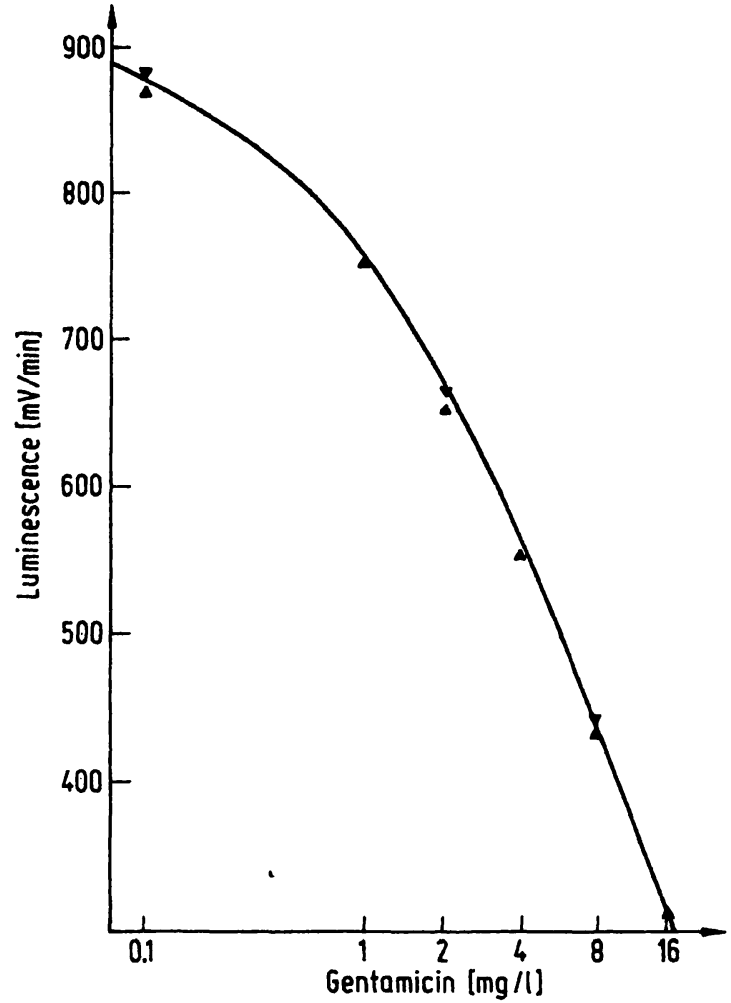

Fig. 3. This shows a gentamicin standard curve for the sequential assay shown in table 2 . The zero standard is set at $0.1 \mathrm{mg} / \mathrm{l}$.

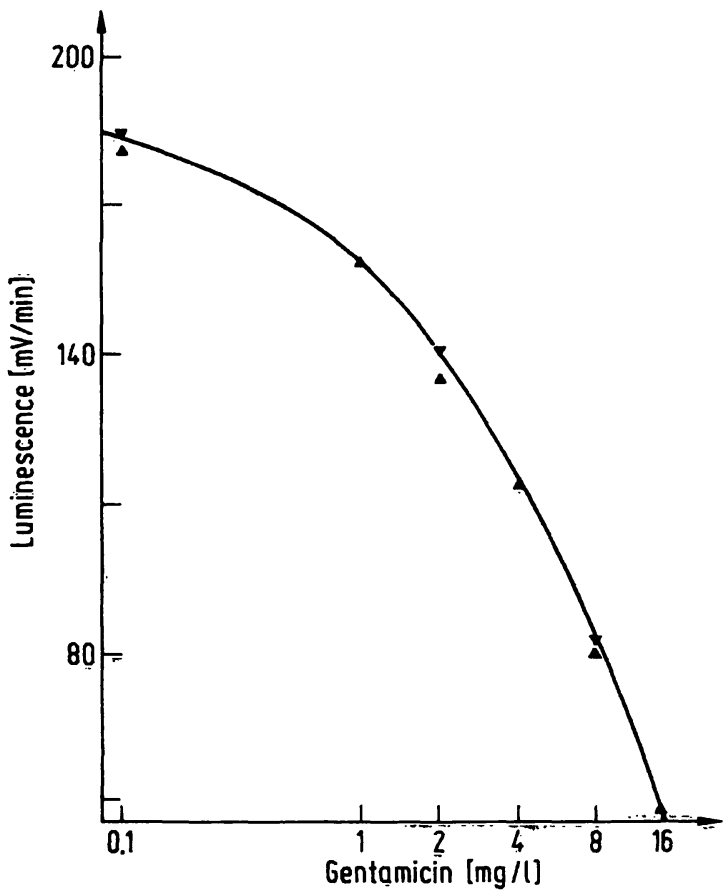

Fig. 4. This shows an exämple of thè competitive gentamicin assay described in table 2. The light generation is much slower than in figure 3 due to the lower amount of solid-phase antigen used.

$\overrightarrow{\text { P.RA }}=$ Radioassay using ${ }^{125}$ I-labelled porcine insulin as antigen P-LIA = SPALT assay using solid phase porcine insulin.

B-LIA = SPALT assay using solid phase bovine insulin.

These patients were carefully selected for an tibodies which were specific for only one insulin-variety. Patient I-763 had antibodies which reacted with both porcine and bovine insulin. Most patients with insulin-antibodies react in a similar way to I-763 serum.
Tab. 5. Correlation between the routine RIA-methods and the SPALT assays for both insulin and gentamicin.

Relevant statistical data

Gentamicin

Insulin

RIA SPALT RIA SPALT

$\begin{array}{llll}\text { Number } & 75 & 75 & 95\end{array}$

of samples

(n)

\begin{tabular}{|c|c|c|c|c|}
\hline $\operatorname{Mean}(\bar{x})$ & 3.58 & $3.60 \mathrm{mg} / 1$ & 13.7 & $13.2 \mathrm{mU} / 1$ \\
\hline $\begin{array}{l}\text { Median } \\
\text { (50th per- } \\
\text { centile) }\end{array}$ & 3.24 & $3.24 \mathrm{mg} / \mathrm{l}$ & 11.7 & $11.4 \mathrm{mU} / 1$ \\
\hline $\begin{array}{l}\text { Relative } \\
\text { scattering } \\
\left.(\text { C.V. })^{*}\right)\end{array}$ & 0.948 & 0.966 & 0.633 & 0.657 \\
\hline Range & $0.11-12.6$ & $0.11-13 \mathrm{mg} / \mathrm{l}$ & $2.2-39.4$ & $2.0-40$. \\
\hline
\end{tabular}

\section{Regression analysis}

The regression equation $y=a+b x$ was used, RIA values being entered as $\mathrm{x}$ in each case.

$\begin{array}{lcc} & \text { Gentamicin } & \text { Insulin } \\ \begin{array}{l}\text { Correlation } \\ \text { coefficient }(r)\end{array} & 0.998 & 0.896 \\ \begin{array}{l}\text { Intercept } \\ \left(a_{\mathbf{y x}}\right)\end{array} & -0.064 & 0.897 \\ \text { Slope }\left(b_{\mathbf{y x}}\right) & 1.02 & 0.898\end{array}$

Standard error of the estimate $y$ from $x$

$\begin{array}{lll}\begin{array}{l}95 \% \text { confidence } \\ \text { limits }\end{array} & 0.379 & 7.68 \\ \begin{array}{l}99 \% \text { confidence } \\ \text { limits }\end{array} & 0.569 & 11.5 \\ \begin{array}{l}\text { Lambda } \\ \text { value }\end{array} & 0.186 & 4.27\end{array}$

The data used was normally distributed - i.e. was not significantly different from a Gaussian distribution curve.

*) The coefficient of variation was used as the measure of dispersion of the values used in the calculations above.

Tab. 6. Comparison of radio- and luminescent assay data for the detection of insulin antibodies as described in table 3 method 1.

\begin{tabular}{llllll}
\hline Patient No. & $\begin{array}{l}\text { Age } \\
\text { (a) }\end{array}$ & Insulin & $\begin{array}{l}\text { Ratio } \\
\text { P-RA }\end{array}$ & $\begin{array}{l}\text { Ratio } \\
\text { P-LIA }\end{array}$ & $\begin{array}{l}\text { Ratio } \\
\text { B-LIA }\end{array}$ \\
\hline I-370 & 60 & Porcine & 1.69 & 1.81 & 0.96 \\
I-390 & 16 & Porcine & 4.38 & 6.03 & 1.48 \\
I-441 & 61 & Porcine & 6.05 & 4.98 & 0.65 \\
I-469 & 17 & Porcine & 4.13 & 4.55 & 1.14 \\
I-475 & 17 & Porcine & 4.20 & 4.74 & 1.04 \\
I-493 & 60 & Porcine & 1.51 & 1.36 & 1.21 \\
I-580 & 34 & Porcine & 3.60 & 3.98 & 1.85 \\
I-592 & 24 & Porcine & 2.40 & 1.99 & 1.39 \\
I-601 & 18 & Porcine & 2.20 & 4.15 & 0.77 \\
I-695 & 22 & Bovine & 1.14 & 1.37 & 6.43 \\
I-763 & 47 & Bovine & 3.00 & 2.76 & 5.84 \\
& & & & & \\
Negative & - & none & 1.10 & 0.98 & 0.89 \\
controls & - & none & 0.97 & 1.14 & 1.06 \\
& - & none & 1.04 & 0.94 & 0.99 \\
Severe & 72 & none & 0.94 & 2.44 & 3.02 \\
haemolytic & & & & & \\
anaemia & & & & & \\
\hline
\end{tabular}


Tab. 7. Rulevant statistical data comparing the performance of the RIA and SPALT assays for insulin andigentamicin in serum.

Precision profile, shows the distribution of the coefticients of variation for the mean of duplicate values covering the range between the lowest and highest detectable concentrations for each assisty'."

\begin{tabular}{|c|c|c|c|c|c|c|c|c|}
\hline Assiay & $\left.\mathrm{ns} / \mathrm{na}{ }^{*}\right)$ & $\begin{array}{l}\text { Concentration } \\
\text { Range }\end{array}$ & Median & $\begin{array}{l}\text { Percentil } \\
2.5\end{array}$ & 16 & 50 & 84 & 97.5 \\
\hline $\begin{array}{l}\text { Gentamicin RIA } \\
\text { Gentamicin SPALT }\end{array}$ & $\begin{array}{l}95 / 17 \\
95 / 17\end{array}$ & $\begin{array}{l}0.11-12.6 \mathrm{mg} / 1 \\
0.15-12.2 \mathrm{mg} / 1\end{array}$ & $\begin{array}{l}2.30 \mathrm{mg} / 1 \\
2.50 \mathrm{mg} / 1\end{array}$ & $\begin{array}{l}1.97 \\
1.08\end{array}$ & $\begin{array}{l}4.30 \\
2.20\end{array}$ & $\begin{array}{l}7.50 \\
5.60\end{array}$ & $\begin{array}{l}13.7 \\
12.3\end{array}$ & $\begin{array}{l}23.4 \% \\
21.8 \%\end{array}$ \\
\hline $\begin{array}{l}\text { Insulin RIA } \\
\text { Insulin SPALT }\end{array}$ & $\begin{array}{l}122 / 13 \\
122 / 13\end{array}$ & $\begin{array}{l}2.20-106 \mathrm{mU} / 1 \\
2.70-118 \mathrm{mU} / \mathrm{l}\end{array}$ & $\begin{array}{l}11.4 \mathrm{mU} / 1 \\
10.9 \mathrm{mU} / \mathrm{l}\end{array}$ & $\begin{array}{l}2.00 \\
1.98\end{array}$ & $\begin{array}{l}3.30 \\
3.71\end{array}$ & $\begin{array}{l}6.30 \\
5.40\end{array}$ & $\begin{array}{l}12.5 \\
10.3\end{array}$ & $\begin{array}{l}26.1 \% \\
19.7 \%\end{array}$ \\
\hline
\end{tabular}

Percentiles have been used as the data were not normally distributed. The values under the percentịle headings rẹpresent the precision in percent lying equal to or below the percentile value. For example, for the gentamicin SPALT assay $50 \%$ of all precision values. lie under $5.6 \%$.

Inter-and Intra-assay coefficients of variation for two control sera lying in the lower and upper parts of the standard (dose-response) curve

Assay

Intra-assay

n $\frac{\text { RIA }}{\mathrm{x}}$

Gentamicin

$20 \quad 3.84 \mathrm{mg} / 1$

$20 \quad 10.5 \mathrm{mg} / \mathrm{l}$

Insulin

\begin{tabular}{llll} 
CV & & \multicolumn{2}{l}{ SPALT } \\
$(\%)$ & $\mathrm{n}$ & $\overline{\mathrm{x}}$ \\
& & & \\
3.87 & 20 & 4.10 & $\mathrm{mg} / \mathrm{l}$ \\
6.67 & 20 & 10.3 & $\mathrm{mg} / \mathrm{l}$ \\
4.88 & 20 & 18.6 & $\mathrm{mU} / 1$ \\
6.41 & 20 & 136 & $\mathrm{mU} / 1$
\end{tabular}

\begin{tabular}{|c|c|c|c|}
\hline & \multicolumn{3}{|c|}{ Inter-assay } \\
\hline $\begin{array}{l}\text { CV } \\
(\%)\end{array}$ & & $\overline{\mathbf{R}}_{\bar{x}}^{\text {RIA }}$ & \\
\hline $\begin{array}{l}5.27 \\
4.93\end{array}$ & $\begin{array}{l}20 \\
20\end{array}$ & $\begin{array}{c}4.06 \\
10.7\end{array}$ & $\mathrm{mg} / \mathrm{l}$ \\
\hline 26 & 20 & 25.1 & $\mathrm{mU} / \mathrm{t}$ \\
\hline 9 & 20 & 117 & $\mathrm{mU} / \mathrm{l}$ \\
\hline
\end{tabular}

\begin{tabular}{|c|c|c|c|}
\hline $\begin{array}{l}\mathrm{CV} \\
(\%)\end{array}$ & $\mathrm{n}$ & $\underset{\overline{\overline{\mathbf{x}}}}{\text { SPALT }}$ & $\begin{array}{l}\mathrm{CV} \\
(\%)\end{array}$ \\
\hline 8.9 & $\begin{array}{l}15 \\
15\end{array}$ & $\begin{array}{r}4.21 \mathrm{mg} / \mathrm{l} \\
10.5 \mathrm{mg} / \mathrm{l}\end{array}$ & $\begin{array}{l}5.35 \\
6.75\end{array}$ \\
\hline 7 & $\begin{array}{l}15 \\
15\end{array}$ & $\begin{array}{l}24.2 \mathrm{mU} / \mathrm{l} \\
124 \mathrm{mU} / \mathrm{l}\end{array}$ & \\
\hline
\end{tabular}

The standards used in both methods were identical. .

*) ns/na denotes number of samples/number of assays.

The introduction of a solid-phase antigen assay is in principle nothing new, as this type of immobilisation of antigens has formed part of the in-vitro laboratory diagnosis of hepatitis and specific allergies (RAST test). The use of an immobilised antigen and an iodinated second antibody as "universal label" has also been recently published for haptens in a competitive assay $(1,2)$. The novelty of the SPALT is its capability to measure both proteins and haptens without radioactivity, and with a sensitivity equal to that obtainable in radioimmunoassay. The sensitivity of the SPALT insulin assay, defined as the lowest detectable concentration or the value read off the standard curve using a count-rate 2 standard deviations lower than the mean zero standard countrate, is under $5 \mathrm{fmol}$ per tube (equivalent to $<3 \mathrm{mU} / \mathrm{l}$ ) for the routine assay using a $100 \mu \mathrm{l}$ serum sample.

The use of a sequential assay technique has all the advantages of the immunoradiometric type of assay inasmuch as an excess of solid-phase antigen can be used, as well as an excess of labelled second antibody. The precision of the assay depends to a large extent upon the first step of the assay, i.e. the pipetting of sample and first antibody. The form of the standard curve is similar to that of a conventional radioimmunoassay, i.e. maximal signal at minimal analyte concentration, so that the signal at this concentration corresponds to an almost $100 \%$ "bound tracer signal".

The use of a second antibody label, apart from its universal application to all assays using a commonspecies first antibody, means that the reagents used in the first reaction step may contain preservatives norm- ally found in radioimmunoassay systems, e.g. sodium azide, as these are removed from the system during the first wash step, i.e. before addition of the pyruvate kinase labelled second antibody. Problems can arise when a choice of preservative for the second antibody solution has to be made. Addition of antibiotics to the reconstituted label appear to have no deleterious effects, bearing in mind that the choice of antibiotic may be critical, as in the gentamicin assay for example.

The insulin assay here described shows that the optimal signal to blank ratios are obtained with assay $E$, that is, an assay with a three day incubation, although acceptable sensitivity and precision can be obtained using shorter assay times. The optimal design lies in the choice of both first and second antibodies, and also upon whether the antibodies are purified before use, (1). The general opinion now appears to favour the use of monoclonal second antibody for labelling, not only because of specificity, but also because of the purity of the reagent which can be obtained (Voller, A. \& Hunter, W. M., personal communications).

The gentamicin assay can either be performed as a sequential or competitive assay, the latter resulting in a quicker assay, but lower signal as the solid-phase antigen must be present at much lower concentrations. The use of excess reagents allows for a greater margin of error in pipetting and is reflected in the precision obtained for the assays here described. Using a specific solid-phase insulin allowed the detection of monospecific antibodies to either porcine or bovine insulin in a small number of patients, although, as stated 
above, most patients had antibodies which bound both. An important criticism of the SPALT assay as described here, is the need for thorough washing of the solid-phase between steps. Before such an assay can have a chance, commercially speaking, a solid-phase must be developed which is easy to handle, and if possible, easy to wash without having to use a centrifuge-step. Preliminary results show that in the case of larger antigens such as thyroxine binding globulin (TBG), treated glass balls can replace microcrystalline cellulose as a support to which the TBG is covalently coupled. Whether a similar technique can be used for haptens is still to be seen, although the results of Stafford and Kilgallon $(1,2)$ show that it should be possible.

Superficial studies show that there is nothing to stop other labelled second antibody preparations being used in a solid phase antigen technique. Replacement of pyruvate kinase by azoluminol leads to a SPALT assay using a chemiluminescent detection system (6). This type of assay has also been used to measure gentamicin using an identical assay system as here described. Peroxidase labelled second antibody has been used to detect the presence of gonococcal antibodies using a gonococcus extract covalently attached to microcrystalline cellulose (Wood, unpublished data). Although bilirubin in concentrations up to five times the upper limit of the normal range have had no effect on the results, the possibility exists that haemolytic serum may contain sufficient pyruvate kinase to affect the results.
To remove such effects, pyruvate kinase inhibitors can be added to the first incubation step, provided that the concentrations used allow a complete removal from the system before the second antibody incubation step. Lipaemic sera affect the SPALT in the same way as a normal radioimmunoassay inasmuch as the large amounts of fats inhibit the antibody-antigen reactions, as well as swamping the solid-phase antigen.

In the search for a more acceptable solid-phase for haptens, it cannot be excluded at this stage that an alternative to pyruvate kinase may have to be found, as it appears that the second antibody-pyruvate kinase may be sterically hindered from binding to the first antibody-antigen complex when using a high-density solid-phase such as glass or activated Teflon. An attractive alternative, at least on paper, is adenylate kinase (EC 2.7.4.3) because of its low molecular weight (21000) and stability against heat and $\mathrm{pH}$-changes.

As with all new techniques, the impact of the luminescence immunoassays as described here depend upon the availability of automated luminometers, as well as robust commercial kits.

\section{Acknowledgements}

The authors would like to thank Wallac Oy, Turku, Finland, and LKB, Duisseldorf, FRG, for their support in providing the luminometer used in this study, as well as the ATP-monitoring reagent.

\section{References}

1. Kilgallon, W. \& Stafford, J, E. H. (1982) Clin. Chim. Acta $120,181-190$.

2. Stafford, J. E. H. \& Kilgallon, W. (1980) J. Immunol. Meth. 34, 339-343.

3. Fricke, H., Strasburger, C. J. \& Wood, W. G. (1982) J. Clin. Chem. Clin. Biochem. 20, 91-94.

4. Barnard, G., Collins, W. P., Kohen, F. \& Lindner, H. R. (1981)

In: Bioluminescence and Chemiluminescence - Basic

Chemistry and Analy tical Applications (DeLuca, M. \& McElroy, W. D., eds.) Academic Press, New York, Londōn, Toronto, Sydney and San Francisco, pp. 311-317.

5. Kitagawa, T. \& Aikawa, T. (1976) J. Biochem. 79, 233-236. 6. Strasburger, C. J., Fricke, H. \& Wood, W. G. (1982) Fresenius Z. Anal. Chem. 311, 351-352.

Dr. W. G. Wood

Klinische Laboratorien

Klinik für Innere Medizin

Medizinische Hochschule Lübeck

Ratzeburger Allee 160

D-2400 Lübeck 1 
